\title{
Indian Folk Music and 'Tropical Body Language': The Case of Mauritian Chutney
}

\section{Catherine Servan-Schreiber}

\section{OpenEdition}

\section{Journals}

Electronic version

URL: http://journals.openedition.org/samaj/3111

DOI: 10.4000/samaj.3111

ISSN: 1960-6060

\section{Publisher}

Association pour la recherche sur l'Asie du Sud (ARAS)

\section{Electronic reference}

Catherine Servan-Schreiber, «Indian Folk Music and 'Tropical Body Language': The Case of Mauritian Chutney », South Asia Multidisciplinary Academic Journal [Online], Free-Standing Articles, Online since 24 January 2011, connection on 19 April 2019. URL : http://journals.openedition.org/samaj/3111 ; DOI : 10.4000/samaj.3111

\section{(C) $\Theta \Theta \Theta$}

This work is licensed under a Creative Commons Attribution-NonCommercial-NoDerivatives 4.0 International License. 


\title{
samaj South Asia Multidisciplinary Academic Journal
}

Servan-Schreiber, Catherine (2011) 'Indian Folk Music and 'Tropical Body Language': The Case of Mauritian Chutney', South Asia Multidisciplinary Academic Journal. URL: http://samaj.revues.org/index3111.html To quote a passage, use paragraph (§).

\section{Indian Folk Music and 'Tropical Body Language': The Case of Mauritian Chutney}

\author{
Catherine Servan-Schreiber
}

\begin{abstract}
In Mauritius, the meeting between Indian worlds and Creole worlds, through the migration of the indentured labour which followed the abolition of slavery in 1834, gave birth to a style of music called 'chutney'. As a result of the African influence on an Indian folk genre, chutney music embodies the transformation of a music for listening into a music for dancing. In this article, the innovations brought into the choreographical dimension of the chutney groups will be taken as a key to understanding the adaptation of Indian rural migrants to a new 'Indian-oceanic' way of life through the experience of diaspora.
\end{abstract}




\section{Introduction}

[1] What the Mauritian is going through at the moment is a gradual (and almost imperceptible) dilution of traditional lifestyle and values, so that Asian communities are brought closer to 'general population'. Certainly in a few generations' time, everybody will be living a more or less Creole lifestyle (Ngcheong-Lum 2003: 56). ${ }^{1}$

[2] In the Indian Ocean, the meeting between Indian and Creole worlds, through the migration of the indentured labor which followed the abolition of slavery in 1834, gave birth to a style of music called 'chutney'. This term, which connotes a 'spicy' music, is also referred to as chatkar (flavour, explosive) or dhamaka (big sound, explosion). Whereas bhangra music comes from Punjab, the origin of chutney music lies in the rural folk music of Eastern India, namely in the Bhojpuri-speaking regions of Bihar and Uttar Pradesh. Arrival in Mauritius, cohabitation with the Creole population, working in the sugarcane factory, discovering sega music and the ségatier musician completely changed musical perception, practice and technique of composition. While studying the chutney music of Trinidad and Surinam, Peter Manuel (2000), Helen Myers (1998) and Tina Ramnarine (1996) explored the relation between Indian folk music, Guyanese kaseko² and Trinidadian calypso, but little is known about chutney as a Mauritian musical expression.

[3] If we examine the historicity of this musical form, we can see that it is linked to three transitional periods in the development of Mauritius as a nation. Firstly, it comes from the introduction of indentured labour of Indian origin into the sugarcane economy and the world of colonial plantations (1834-1884). Secondly, it has to do with the industrialization of the rural sector and the experimentation of the system of 'l'usine aux champs' (the factory in the fields). Thirdly, it is linked to the redeployment of a new schema of migration towards the Western countries which especially affected the youth, aggravating the frustrations of an entire generation.

[4] As a result of the African influence on an Indian folk genre, ${ }^{3}$ chutney music embodies the transformation of a music for listening into a music for dancing. In this regard, the innovations

\footnotetext{
1 The population of Mauritius is composed of the following. $68 \%$ of people are of Indian origin: $51 \%$ Hindus, largely subdivided along various ethnic and regional lines (Hindi speaking and Tamil speaking) and $17 \%$ Muslims. Chinese are $1 \%$ (mainly from Hakka culture with some Cantonese speakers). Finally, $30 \%$ is considered 'general population' whose common denominator is some adhesion, active or simply symbolic, to Christianity.

2 Kaseko is a Guyanese dance whose name comes from the French language casser le corps (breaking the body).

3 On this music, see O'Henry (1988) and Servan-Schreiber (1999, 2003).
} 
Servan-Schreiber, Catherine (2011) 'Indian Folk Music and 'Tropical Body Language': The Case of Mauritian Chutney', South Asia Multidisciplinary Academic Journal. URL: http://samaj.revues.org/index3111.html To quote a passage, use paragraph (§).

brought into the choreographical dimension of the chutney groups will be taken as a key to understanding the adaptation of Indian rural migrants to a new 'Indian-oceanic' way of life through the experience of diaspora. Creole and creolization in the Mauritian context are distinct from their West Indian counterparts. In Mauritius, 'the political nature of the term Creole suggests several things. First, that the category is still in the process of ethnogenesis and that existing interpretations of Creole-ness and Creole identity are being reviewed; second, that Mauritians are moving away from strictly cultural definitions of group identity, and third, that the Creole category is culturally open' (Boswell 2003: 21). In this context, Creoles are specifically those with ancestors from Africa, not any other communities that also came to settle. Creolization firstly refers to the African influence in musical genres, but also more generally to musical mutations stemming from contacts between distinct cultures.

\section{The circulation of musical forms and the discovery of sega}

[5] Mauritian chutney music had a life of its own well before its Caribbean cousin, despite its delayed official recognition. Caribbean, especially zouk and reggae influence, is only a recent aspect of the Indian-oceanic process of contact and exchange. The origins of Mauritian chutney go back to the first settlements that came up around the plantations, at a time when Indian communities had just begun to arrive in the Caribbean.

[6] Sugar cane plantation slaves used to dance 'during night feasts far from the colonist house on the rhythm of the Malagassy salega and the Mozambican tschiéga or chéga' (Ballgobin \& Antoine 2003: 76). Contrary to many assumptions that sega was despised by the population of Indian origin, the rural community of the so-called 'back country', that is to say the parts of land near the sugarcane plantations where the indentured labour first settled, was deeply concerned by this music. The Mauritian musicologist and renowned teacher of Indian classical music Iswarduth Nundlall (1984: 47), coming himself from the Indian urban elite, took the trouble to define sega as 'the expression of Creole genius' in his analysis of Mauritian music. He explained how interesting the discovery of sega was as a dancing rhythm and a technique of improvisation. He evaluated similarities with the nayaki and gayaki, Indian musical styles, notwithstanding the fact that in sega, not only the melodies, but the lyrics also are improvised. Far from relating it to the Creole sense of idleness or indecency, as did the European travellers of the 19th century, he saw in this music 'the aptitude of a population to live in the present moment'. Though its initial use was a form of protest song and complaint of slavery, nowadays the raison d'être of sega, is also to met la faya (to make 
Servan-Schreiber, Catherine (2011) 'Indian Folk Music and 'Tropical Body Language': The Case of Mauritian Chutney', South Asia Multidisciplinary Academic Journal. URL: http://samaj.revues.org/index3111.html To quote a passage, use paragraph (§).

people dance). This was the basis of its success inside and outside the Creole world. For Iswarduth Nundlall, this was a music so lively that no one can listen without taking part. This appreciation was fully shared by the Indian professional musical field: 'We like sega', comments Ravin Sowamber (2003), leader of the Bhojpuri Baja Baje Boys, 'because we speak the language and we understand the lyrics, but it's also for the dance'.

[7] As underlined by Stéphane Dorin (2005) in his sociological study of jazz in Calcutta, the role of places where musical forms could circulate has to be taken into account. While the plantation system and the camp mode of habitation were long considered by the historians of indentured labour as harmful to the development of musical expression, not only did they allow for the perpetuation of musical habits, they also favoured innovations. Suchita Ramdin (2006), a well-known scholar on Bhojpuri music, herself having shared the culture of a tea estate in her childhood, considers that the camp was more favourable to the development of Indian popular music than later the village settlements, which were open to so many external influences.

[8] Very early, as attested to by historical and literary sources, mutual musical discoveries took place. In Mauritius, where family histories are often shrouded in silence, and sound recordings from the past also a rarity, literature fills the gap in some measure. Access to literary documentation thus remains an important window to shared cultural practices. Inside the plantations, all the newly freed labour had not left. Places like maisons de maîtres (the masters' houses), wherein some former slaves were still working as domestic help (especially Malagasy people), were acting as relais (medium) of musical discovery, as in the Caribbean. ${ }^{4}$ The shops of the Chinese traders, where everyone met, also provided opportunities for exchange. ${ }^{5}$ According to testimonies, leisure and more specifically drinking habits during evening hours would bring people together. In their isolated situation, the young indentured were pleased to share musical evenings and to be admitted in the sega circles. So doing, they entered new cultural universes. Mentions of their musical discoveries can be found in Deepchand Beeharry's novel That Others Might Live: 'Like most men who had

\footnotetext{
${ }^{4}$ See the film Biguine by Guy Deslauriers, in which we can see the circulation of musical forms in Saint-Pierre, Martinique, between European and Creole worlds.

5 'Most of the men inside the Chinese shops were immigrants while the rest were Creoles of African origin' (Beeharry 1976: 52).
} 
Servan-Schreiber, Catherine (2011) 'Indian Folk Music and 'Tropical Body Language': The Case of Mauritian Chutney', South Asia Multidisciplinary Academic Journal. URL: http://samaj.revues.org/index3111.html To quote a passage, use paragraph (§).

nobody waiting for them at home, Manish spent his evenings with other workers. A few Creoles and quite a lot of Malgaches. They lived mostly on the outskirts of the town, and could be seen, in the evening, at nightfall, sitting in their yards or in the verandah of nearby shops singing or dancing the sega' (Beeharry 1976: 240). In the maison de maître of a White colon, where he is working as a cook, a Creole man named Tatave introduces the coolie Manish to the sega tradition:

- On week-ends, both young men and women meet under the coconut trees and dance. But we do not, like the Whites when they dance, hold each other's hands or wrists. No, we stand about one foot from each other and dance to the beats of the ravanne.

- I am sorry, I do not know what is a ravanne. I know of the ten headed opponent of Rama who was called Ravana.

- No, this ravanne is a musical instrument, large and round in shape. You know, of course, what is a tambour, a dholak, well, ravanne is a sort of dholak with one side only, but it has no body at all, like the dholak. Man, why don't you come? l'll get any girl to teach you how to bouger bouger.

- What's that?

- Bouger means shake, you shake your waist backward and forward too.

- Do you think people will object?

- Pas tracas! No worry! At a sega party, people dance, drink, enjoy themselves. They let themselves go. Who cares for colour or race? When the ravanne heats up you forget everything and you let yourself go. Cause cause en bas en bas (Beeharry 1976: 181).

[9] Later on, another Creole friend named Paulo will initiate him to the sega performance:

All the time Manish had been there watching the dancers turn and twist their bodies to the sound of the ravanne and the drums. He learnt to love the sega, ever since the evening he had been together with the young cook to the party. After all, he said to himself, I have seen something like it at home. Santhal tribal people and even village folk dance it to, perhaps, different instruments. So during the evenings, when Paulo was free, they would both go down to Les Casernes, where almost everyday sega parties were held. Then, it became a regular habit (Beeharry 1976: 241).

[10] In addition to the improvised evenings of sega performance, other places played an important part in musical discovery. The Creole bash created an important opportunity:

You have to attend a Creole wedding to understand the intensity with which this community devotes itself to merrymaking. After the cake has been cut and everybody serves a slice, the bride and bridegroom open the ball with a Viennese waltz. Afterwards all kinds of music are played, with sega being the most popular. Every one joins in the fun, children dance with their grandparents, and many try to have a dance with the bride (NgCheong-Lum 2003: 91). 
[11] Ravin Sowamber described his own discovery of sega:

When we are invited to a Creole wedding, we do not say, 'we are Hindu, we do not dance the sega'. Since my father was a tailor, he made me a good suit, so that I would look elegant at a Creole wedding. We are born here, and we grew up with descendants of African slaves, so why should we ignore each other? (Sowamber 2003).

[12] A third crucial place for the circulation of musical forms was the fancy fair. The fancy fair, as a charity fair, took place in the courtyard of churches and was regularly organized by every parish on Sundays. It included a meal of briani, ${ }^{6}$ beer drinking, a clothing market, games, and sega music performances. The greatest ségatiers like Ti-Frère, Serge Lebrasse, Gérard Louis, Michel Legris, started on the platform of fancy fairs. These spaces were not closed, but open to non-Christians. Many an indentured labourer, and later on, many Indo-Mauritians, even non-converted Tamil people would attend these specific events of Mauritian sociability.

\section{The path of the musician and the stakes of chutney music}

[13] In the reconstitution of the history of chutney music, the study of the musician's path and his life story enables us to perceive the contradictory concerns and challenges he faced: displaying an 'Indian' inheritance inscribed in a folk tradition, and at the same time, showing his 'modernity' and belonging to a Creole environment, as well as showing to the Mauritian society as a whole that his music was meant for all Mauritians, and provided as satisfying an incentive for moving bodies and dancing as Creole music.

[14] As the journalist Sedley Assonne deplored in his biography of the ségatier Gérard Louis, practically no attention is given in Mauritius to the personal history of the singer: 'in Mauritius, people are satisfied with listening to a tune. Nobody cares to know where the singer comes from' (Assonne 2004: 15). My study of the 300 singers who collectively constitute the field of chutney music reveals that the milieu is fairly homogeneous. From indentured workers established in rural or semi-urban zones, previously linked with sugarcane, most of the Indian hinterland (countryside) people were reoriented towards the textile industry as factory-workers, or became vegetable-growers, grocers, customers, stretcher-bearers.

\footnotetext{
${ }^{6}$ Mauritian pronunciation for biriani.
} 
Servan-Schreiber, Catherine (2011) 'Indian Folk Music and 'Tropical Body Language': The Case of Mauritian Chutney', South Asia Multidisciplinary Academic Journal. URL: http://samaj.revues.org/index3111.html To quote a passage, use paragraph (§).

[15] Through his social status and education, the chutney singer shares common characteristics with other Indian Ocean musicians. Like the Creole ségatier, he often starts in a religious surrounding and succeeds through a TV or radio contest. He is not a full-time artist, he has another job, and tries his best to save time for his music. Yet, he maintains a specific personality, owing to his extremely diversified sources of inspiration: his inheritance includes the Indian medieval mystical tradition, the latest Bollywood film music, African rhythm, the classical-light 19th century European music through operettas and waltzes, modern disco and pop, from Europe and America.

[16] Similar to the European composer studied by Pierre-Michel Menger (2001) or the flamenco musician Lucas Carmona filmed by Michael Meert, the chutney singer follows his family's (father, uncle) hereditary tradition. He begins in a temple by singing religious hymns, bhajans and kirtans, and/or performs on the occasion of the gamat, the Saturday night musical event linked to the wedding reception, inside la tente mariage (green tent or wedding tent). He quite often wishes to get instruction in vocal Hindustani music, and therefore seeks out the help of a teacher. He takes part in numerous, not to say endless contests, not only at a national or international level, but also among the chutney singers themselves. ${ }^{7}$ His greatest ambition: to be allowed to play in Mauritian hotels for tourists, like the Creole ségatier, and to be invited on European stages. As the Malagasy musician studied by Julien Mallet (2008), he sings devotional songs in the temples, plays pop music on stage and provides musical wedding entertainment; he also performes in numerous social functions (house-warming, birthdays, political meetings, trade union meetings, and so on). Yet, because he is not as famous as the Creole musician, he has to constantly negotiate, even more arduously than the ségatier, his participation in stage concerts and his insertion into the World Music networks.

[17] Here are the lyrics of some of them:

I live in Rivière des Créoles, near Mahébourg. I was born in a very poor family of labourers, sugar-cane field workers. My grandfather was a musician. He would play (the) violin. I used to love music, and I also loved the kavis, the poets, the bhajans, the kirtans, and the folk songs of the coolies. I started singing at around. Now I have a troupe of dancing girls. When our ancestors came, when we arrived in Mauritius, we discovered the sega music. We like the sega music of Serge Lebrasse and Ti-frère, because it has two common traits with our music. It tells about ancient times and the ancestors, but it also talks about change and a possible new world. We also include chule, whistlings, because it is the Mauritian style... (Sewpaul 2006).

\footnotetext{
7 Including the most famous Bhojpuri Bahaar (song contest) on TV, very similar to the Trinidadian Bhojpuri Bahaar.
} 
I was born in 1941. I created the Dhamaka group. My ancestors came from Bihar, 150 years ago. My father was a barber, he would play harmonium and banjo. My mother would sing traditional wedding songs in Bhojpuri. I started by learning cantiques. I belong to Arya Samaj [a religious reform movement], but the sega rhythm is essential to me (Nuckcheddy 2006).

My father was a charcoal-burner in Brisée-Verdière. Where did my family come from? From Africa? From Mozambique? From Madagascar? I do not know. When I was born, in 1943, we were too poor to go to school. But the baithka [Indian education system] was free, and I wanted to learn. I bought a bal shiksha [an alphabet] for two rupees. I learned the Hindi alphabet. Slowly slowly I learned the letters. I took lessons in vocal Hindustani music with a Pandit of Chemin Grenier and I became a chutney singer (Lagare 2006).

[18] The Gowry Brothers (twin singers in their 60s) say that 'We wanted to take Bhojpuri music beyond the sugar estates, leave the wedding-tent and go on the stage. We sang in Bhojpuri and in Creole' (Gowry Brothers 2007). For Anilsingh Ramessur (2007), a 40-year-old radio talk show host and singer, 'We sing chutney. By singing chutney, we become international'. Biswanee Deepoa (2007), a 38-year-old female singer, adds 'We put sega rhythm in our composition. If we do not transform our music in the sega style, nobody will listen to our lyrics, nobody will be interested in our music'.

[19] In the context of migration, the discovery of a different body language and a different attitude towards leisure played a major role. Indian people were perceived as very puritanical, obsessed with saving money to purchase land, and insisting on education as a value. Creole people were perceived as idle and merry-making, but their ability to enjoy life and have fun was also much admired. Progressively, in the musical field, the ability of sega to make people dance was seen as something lacking in Indian folk music. The famous ségatier Ti-Frere explains:

Ban Endyen madam, ban Endyen dir mwa Vilmen, packe Endyen zot dir: 'Tonton, kan u sega la santé kumsa, nu levé, nu trap zup, nu dansé! Sa li bon lagam, sa, li don la gam pu nu dansé [A lot of Indian women they tell me: Uncle, when you sing like this, when you sing this rhythm, we stand up, we catch our skirts, and we dance. It creates an atmosphere, it encourages us to dance] (Le Chartier 1993: 24).

[20] Keeping in mind the historical background of Indian folk music, its differences with sega are vast. In the sega orchestra, instruments form a musical ensemble composed of ravanne, maravanne and triangle. Sega includes onomatopoeias and chule (whistling), to encourage people to 
Servan-Schreiber, Catherine (2011) 'Indian Folk Music and 'Tropical Body Language': The Case of Mauritian Chutney', South Asia Multidisciplinary Academic Journal. URL: http://samaj.revues.org/index3111.html To quote a passage, use paragraph (§).

join the dance circle. In the transformation process of the chutney music, the tempo became faster, sega rhythm was easily adopted. The ravanne percussion was included. Chule were added to encourage the dancers on the stage. Even some new themes similar to those in sega's singers lyrics were incorporated into the chutney inspiration. The choreography question became more delicate because chutney music involves not only writing Indian compositions to a sega rhythm, but also adopting and adapting a type of dance capable of competing with sega performance.

\section{From compromise to innovation: Acquiring a new body language}

[21] For the musicians of Indian origin, the question of adaptation to the sega universe implied not only a transformation of melody but also of choreography. The presence of dancing girls accompanying the groups, as in the sega tradition, became necessary. Yet, Hindu parents would not allow their daughters to perform on stage. They thought it was shameful. 'Previously, many parents did not allow their daughters to sing, not to speak of dance, in public. Even the folk dances were performed only by elderly ladies and married women. Girls were not allowed to dance even in family circles' (Bhagat-Ramyad 2007: 21). Therefore, as explained by Hurry Boodnah (2006), a chutney singer of Petit Sable, 'in the beginning, some Catholic girls used to help the groups by creating and performing choreographies'. Later on, in order to widen the audience to the European and Creole world and gain a prestige that the Indian folk-singing alone did not offer, a complete scenographic reorientation was introduced. The habit of including a troupe of Indian dancing girls began. Yet there were restrictions.

[22] Let us now examine the sega costumes and choreography. The singer is accompanied with dancing girls wearing blouses showing the breasts, showing the belly. Lifting their long skirts they show their thighs and legs. 'For a long time, sega was associated with 'suggestive and lascivious' contortions, and as such, it was frowned upon by the Church and the upper rungs of Creolo-Mauritian society' (Ballgobin \& Antoine 2003: 77). In sega choreography, the woman dances with a male partner, and, though she never touches him, the gestures simulate a sexual relation. ${ }^{8}$

[23] In Surinam or Trinidad, the chutney dancers have fully adopted the Creole swaying and Creole costume. But Mauritian families of Indian origin are not ready to have such a display of the female body. Even when parents allowed their daughters to perform on stage, it was only until they reached marriageable age. Consequently, once they reached the age of 16 or 17 , they stopped

\footnotetext{
8 See the YouTube songs Séga Diva and Kan tambour baté by Nancy Dérougère, and Ti Frère's Papitou.
} 
Servan-Schreiber, Catherine (2011) 'Indian Folk Music and 'Tropical Body Language': The Case of Mauritian Chutney', South Asia Multidisciplinary Academic Journal. URL: http://samaj.revues.org/index3111.html To quote a passage, use paragraph (§).

performing. Therefore they always remained beginners, with little experience, and hardly possessed the womanly seduction of professional ségatières or oriental belly dancers. ${ }^{9}$ The fact that they most often belonged to the singers' families added to difficulties because they were not selected according to real professional criteria.

\section{The scenography of the bhojpuri 'bachelorette party' as a prelude to} chutney

[24] In Bhojpuri Indian villages, folk dancers called laundas (male transvestites) execute what Edward O'Henry has described as 'the pelvian rotation':

The launda is a female impersonator, dancer and singer, who may dance opposite a male dancer playing a male role. His role is an institutional correlate of purdah, that is a role which fits logically with the seclusion of women from public life (there are, however, a few women who dance in formal entertainment groups). The launda's performance ranges from pleasantly sensual to lewd. The launda makes a jerky hip dancing. He circles and turns with a gyrating pelvis, often one hand on his hip and the other behind his head. He might also lean back with his bent legs spread and arms in the air, jerk towards his leering, slightly crouched and pelvis-thrusting partner, who with hand at crotch level motions with his upraised thumb. At low caste gatherings, women sometimes cluster near or around the band and dance with other women, or rarely male kin, in this style (O'Henry 1988: 196).

[25] Their bodily movements differ greatly from the sega dancing approach. Nevertheless, a spirit of fusion is created through the dancing tradition transmitted by women in the wedding ritual context, which provides a basis for a new tropical pattern. During the Mati Kora (a wedding ritual consisting of digging the earth and bringing it back home as an auspicious token), women go outside and pick up a bit of dirt to put near the vedic altar, then they sing and dance performing a downward gesture, a movement considered to be the origin of chutney dance style in Trinidad (Ramnarine 1996). According to Peter Manuel,

Caribbean chutney choreography itself is essentially an Indian folk style, with perhaps greater emphasis on pelvic rotation. The conventions surrounding it, however, are a mixture of traditional Indian and contemporary Creole. In some respects, they appear to be a contextualization of Indian wedding dance customs (Manuel 2000: 174).

\footnotetext{
${ }^{9}$ See the YouTube song Dhobi de classe by Jean-Claude Gaspard.
} 

paragraph (§).

[26] In Mauritius, added to the Mati Kora body language, another kind of dancing contributed to the elaboration of modern group choreography: the performing of git gawai. This is done before the celebration of the wedding at the bride's place as well as the bridegroom's place, corresponding to the bachelor's party and the bachelorette party. During this entertainment, women have 'their spicy rendering' (Boodhoo 1993, 1999). Being considered highly erotic, transgressive and provocative, it is performed by married women, and forbidden to male public and children. The name of the dance is jhumar, from 'to swing, to oscillate'. The body movement is an oriental double sway with the right hip, then with the left hip.

\section{The reinvention of folklore and folk dance choreography}

[27] Except for this specific jhumar choreography, the Bhojpuri traditional folk dance of the villages is perceived as somewhat rudimentary and never attained the fame of the garbho dance in Gujarat or bhangra in the Punjab. In the context of migration, the reinvention of folklore and the recreation of dance choreography become both a stake and an important facet of cultural activity.

[28] The costume is not as erotically attractive as the ségatières blouse, but becomes a compromise between rural Indian style and more voluptuous solutions. In the same way as people travel to Bombay before a wedding in order to purchase the bride's, bridegroom's and wedding party's wardrobe, 'shopping travels' to Bombay are organized to provide stage costumes which hardly look like those of the 'ancestral land'. Colours are sometimes chosen to better match the Creole ambiance. Indian skirts or saris may be exchanged for boleros and sega skirts.

[29] The choreography becomes a mixture of more sophisticated 'village folk' dance, Bollywood gesture, and sega scenography. A new 'folk village style' results, which is partly traditional, partly Creole. Since the dancing girls are not allowed to lift up their skirts, they lift their muslin veils. And they dance rotating around the singer, like in sega. The result was very successful. The reception both in the press and among the public was very enthusiastic. The 'mixture of Indian folk steps and sega dance' was lauded as a 'renaissance' (Legrand 2005).

Figure 1. Picture of Sona Noyan with a dancing girl of his troupe rotating around him (C) Catherine Servan-Schreiber) 
Servan-Schreiber, Catherine (2011) 'Indian Folk Music and 'Tropical Body Language': The Case of Mauritian Chutney', South Asia Multidisciplinary Academic Journal. URL: http://samaj.revues.org/index3111.html To quote a passage, use paragraph (§).

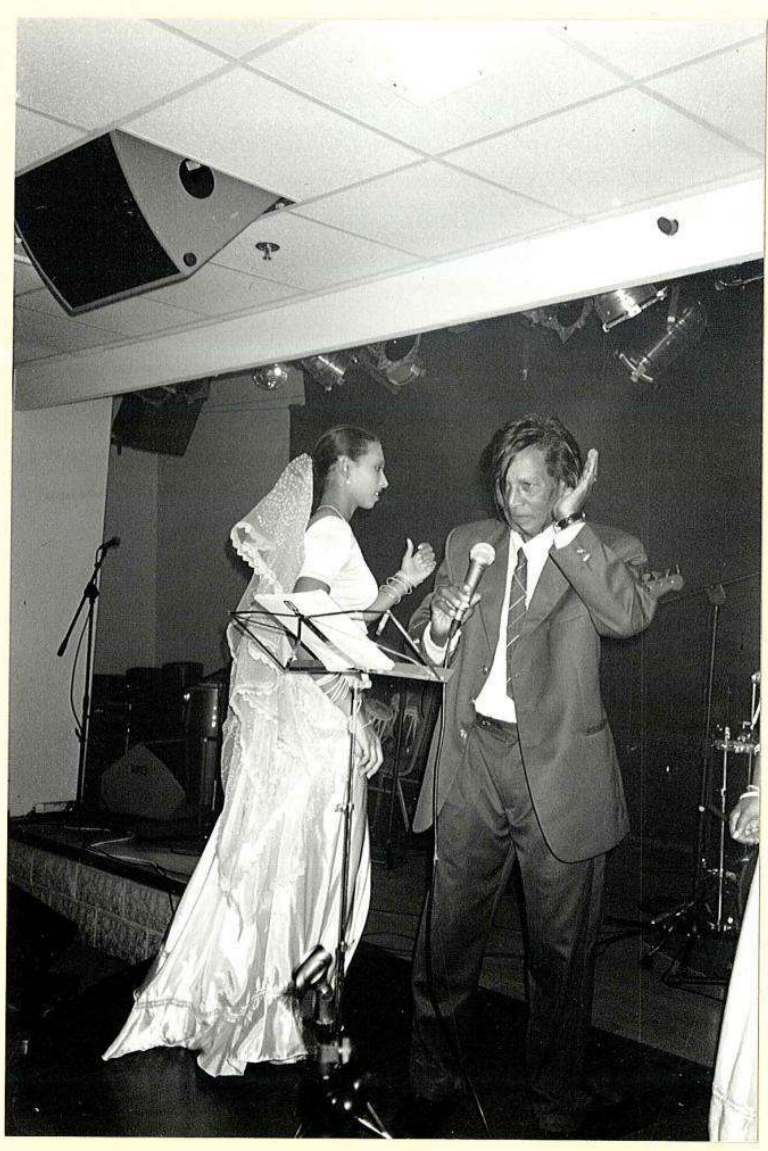


Servan-Schreiber, Catherine (2011) 'Indian Folk Music and 'Tropical Body Language': The Case of Mauritian Chutney', South Asia Multidisciplinary Academic Journal. URL: http://samaj.revues.org/index3111.html To quote a passage, use paragraph (§).

[30] In the era of globalized musical forms, this specific chutney phenomenon is not isolated. In Africa, new 'stage' choreographies are created in a similar fashion. Sarah Andrieu (2008) has shown the discovery and re-appropriation of new choreographic forms, new aesthetics and new ways of using local customs in Burkina Faso, while Elina Djebbari (2008) has analyzed how the Mali national Ballet had been recomposing traditional elements.

\section{The role of 'cultural brokers' and 'identity entrepreneurs'}

[31] In the process of re-creation of folklore and creolization, the central figure of the musical arranger must be emphasized. On each cover of a chutney band's LP, the name of a musical arranger, be it Henriot Figaro, José Mathieu or Claro Bignioux, appears. Several encounters with Henriot Figaro, in the recording studio of Rose-Hill, helped me to comprehend his influence. Acting also as a go-between, he is one of the rare musicians I encountered during my fieldwork who really earns a living with his music. He plays the keyboard, guitar and percussions. Living in Cité Kennedy, at Quatre Bornes, Henriot Figaro had an Indian ancestor, a coach driver from Pondicherry married to a Creole woman. As the name suggests, everyone is addicted to music in the Figaro family, but in a rather European or Creole style. Henriot Figaro's father used to play the banjo, with a double bass. But this leading figure is not the only arranger. Often, people of similar Creole origin play many roles - such as Jean-René Bastien, Pascal Eddy, Yannick Voltrin, Sylvio Lynx, Samuel Paul, Gérard Louis, Desiré Saramandif - and this is true as well for Indo-Mauritians, like Ravin Sowamber or Nand Ramdin.

[32] At another level, cultural entrepreneurs, also considered as 'diasporic leaders' or 'community leaders' (on these notions, see Carsignol 2009), i.e. renowned personalities such as Sarita Boodhoo or Suchita Ramdin, use the reinterpretation and rescuing of tradition as a creative process that in turn influences choreography. ${ }^{10}$ While creating informal or official programmes on the stages of the Mahatma Gandhi Institute and the Mauritius Bhojpuri Institute, they play a major role in Mauritian sociability. Coming from the urban elite, very familiar with the contemporary Indian scene through their professions or militant vocations, they are involved in the reinvention of folklore and 'glamourization' of stern Bhojpuri choreography, rethinking both costumes and body motions. A first step occurred in the 1980s when the Seva Shivir Movement and the Mauritius Bhojpuri Institute,

10 On the use of transforming the folk patrimony or the musical tradition as a creative process, see Sara Le Menestrel (2010). 
Servan-Schreiber, Catherine (2011) 'Indian Folk Music and 'Tropical Body Language': The Case of Mauritian Chutney', South Asia Multidisciplinary Academic Journal. URL: http://samaj.revues.org/index3111.html To quote a passage, use paragraph (§).

launched by Sarita Boodhoo, reasserted the value of the patrimony of Bhojpuri songs that were inherited from 'an ancestral culture' (Boodhoo 1999). The Sit-Basant Hindi-Bhojpuri play was rewritten, for instance. It was followed by regular programmes at the Mahatma Gandhi Institute, such as Parampara by Suchita Ramdin and Nand Ramdin. Gilles Tarabout (2003) has shown the role of cultural entrepreneurs from Kerala who, in the same way, use folk dance or folk theatre patrimonies in order to inspire their own creation. Their aims go beyond mere patrimonalization. Folk arts become also a source of inspiration, combining 'primitivist freshness' and 'the assertion of an originality' (Tarabout 2003: 48). Focusing on Kerala as well, Christine Guillebaud (2008a, 2008b) has shown how the performance scenography of folk village orchestras has changed by being brought on stage or under the impulse of the folk music industry.

\section{Amizer santer danser (enjoy, sing and dance): Adopting Creole values}

[33] As stressed by Peter Manuel (2000: 172) for the Caribbean zone, 'what is dramatically new about modern chutney is not its style but its flouting of the social inhibitions that were previously restricted to dance, and its re-contextualization of a form of public culture enjoyed and performed by men and women together'. He recalls that in the beginning:

Chutney-style dancing was done largely by lower-class women in the sexually segregated context of the wedding and other domestic rituals. Owing to the migratory experience, and through the chutney expression, the dancing practice has been changed from a private confidential feminine custom into an open, public stage performance (Manuel 2000: 171).

[34] Like most dances in India, chutney is not primarily a couple's dance. Two dancers come informally and gyrate near each other on the dance floor and typically part without ceremony or conversation. Yet, in Mauritius, its introduction has changed the relation to dancing in couples, much before the mediatization of Bollywood choreographies. The evolution from the gamat (wedding entertainment music) style to a more modern and spicy style, the equivalent of Caribbean chutney, has followed several steps. Around 1994, new musical groups appeared: Bhojpuri Boys, Bhojpuri Lovers, Bhojpuri Kings, Bhojpuri Melodies, Bhojpuri Baja Baje Boys, Massala Chutnee, Mix Chutnee... Their coloured costumes, their dancing girls and the sound of their fusion melodies struck all audiences.

[35] In 1995, the musical show entitled Traditional Odyssey confirmed the public emergence of the chutney style. Under the impulse of the Mauritius Bhojpuri Institute and the French cultural centre Charles Baudelaire, a musical programme combining jazz, sega, Tamil music, Sufi qawwali songs, 
Servan-Schreiber, Catherine (2011) 'Indian Folk Music and 'Tropical Body Language': The Case of Mauritian Chutney', South Asia Multidisciplinary Academic Journal. URL: http://samaj.revues.org/index3111.html To quote a passage, use paragraph (§).

Bhojpuri folk music (jhumars) and devotional music brought together Linley Marthe, Menwar, Gilles Renne, Philippe Sellam, Kasseven Cunden, Momo Manancourt, Meera Mohun and the group of traditional Bhojpuri female singers of Vallée des Prêtres. Tamil instruments (morlons) and North Indian percussions (dholak, drums) partnered with jazz instruments and European brass instruments.

[36] Sega borrowings and reinvention of Bhojpuri folklore led to adopting, yet changing, the Creole values of entertainment. Specific Creole expressions linked to the field of leisure were translated, though in a more prudish fashion, to Hindi and Bhojpuri. Bouge-bouger, bouger les reins (come on, move your butt) became kamar dolna (move your waist). The Creole credo Amizer santer danser was often quoted in the chutney lyrics.

[37] The chutney singer understands that public dancing is an essential part of Indian merriment. The tent singer (chanteur la tente) hence insists on the fact that his performance is able to create an atmosphere that inspires people to dance. ${ }^{11}$ The song Hum ta nachila (We dance) from the album Mauritian Chutney, by Anilsingh Ramessur and Kavita Mundhill, demonstrates this change of mentality:

Disco mein, gamat mein, ham nachila, Piknik mein, party mein, la tente mein, ham nachila [In the night club, in the wedding party, in the picnic, in the party, in the wedding tent, we dance] / Sometimes it's a party, sometimes it's a wedding party / One plays lota, one plays chimta / Some dance to disco, some to chutney / We dance, we dance! / Let's dance, let's dance!12

[38]Women are progressively allowed to dance in public, even encouraged. Many chutney songs like Natcho béti or Nac ré béti (Dance my daughter) by Pokhun or others like Nac meri jan (Dance my beloved) express this new permissivity, and this changing attitude towards dance. We can see it as well in Hurry Boodnah's Bhojpuri Pop Séga:

Man bhar nach goria, jee bhaarke nach / Sab koyi tora dekhke / Kamaria dolaye / Sab koyi tora dekhke (Dance as long as you wish my pretty / For when they see you / They will all move their waist like you do).

11 Exactly as in Surinam, where chutney singer Kries Ramkhelawan claims 'Indian chutney dance can get people to dance just as well as soca dance does' (Servan-Schreiber 2010).

12 The lota (small round pot of brass or copper) and the chimta (tongs) are used as percussions. 


\section{Women's emancipation through chutney}

[39] Indeed, the topic of the emancipation of rural woman of Indian origin came to inspire many chutney lyrics. This is a new development. For more than a century, chutney music was devoted to the commemoration of the story of migration and indentured labour, describing either the ship (as in 'Slowly slowly the waves moves'), or the crossing of the dark waters (as in 'Kala pani [Black water]'). The bideshiya (the one who expatriates) was the central figure of this migration saga. Numerous songs would celebrate the coolie working in the sugarcane field, showing him as a victim or as a hero. The antagonism with the colonial world and the White man as a figure of hatred were the background of most of the songs. Like in 'Bhojpuri kavita' by Rishideo Rambally (a singer from Petite Rivière): 'From India and Africa, slaves and coolies have been brought together / They sweat and bled together / Even when the UK were beating them, they remained strong'. Nowadays, other causes supply themes to chutney music: mainly, women's empowerment. The woman is no longer a miserable housewife, abandoned by an adventurous migrant. She has to face the problem of male alcoholism, absenteeism and violence. But the songs also show her as seductive, as questioning her situation and speaking openly. This trend of chutney music is reflected in the song 'Dhall pakayli' by Anilsingh Ramessur and Kavita Mundhill: 'I work all day long at the factory / I cook rice and dhallpuris / While you remain idle / Enjoying yourself / Going to the movies'. In Shadi Karke (After marriage), Biswanee Deepoa sings: 'When the husband comes back home/ The wife says: do not leave the house / Do the housework / Don't waste time / Clean up the house / Go and get some water / Bake a cake / Clean up the garage / And no badinage!'

[40] The new migration policy, applied after the recent European legislation on sugar production, allowed the young Mauritian girl to migrate by herself, no longer risking blame for traveling akeli (alone) abroad, as reflected in the songs 'La France' and 'New Departure (Naya Sirey)' by the Bhojpuri Boys. In the YouTube video of 'Naya Sirey', the girl's fiancé remains alone on the sea-shore, while the parents wave their handkerchiefs, as the plane which is taking her to France, for 'a new beginning', flies in the sky.

Figure 2. Thela-Theli by Vinod Sewduth and his dancing girls wearing sega costumes (courtesy of Vinod Sewduth) 
Servan-Schreiber, Catherine (2011) 'Indian Folk Music and 'Tropical Body Language': The Case of Mauritian Chutney', South Asia Multidisciplinary Academic Journal. URL: http://samaj.revues.org/index3111.html To quote a passage, use paragraph (§).

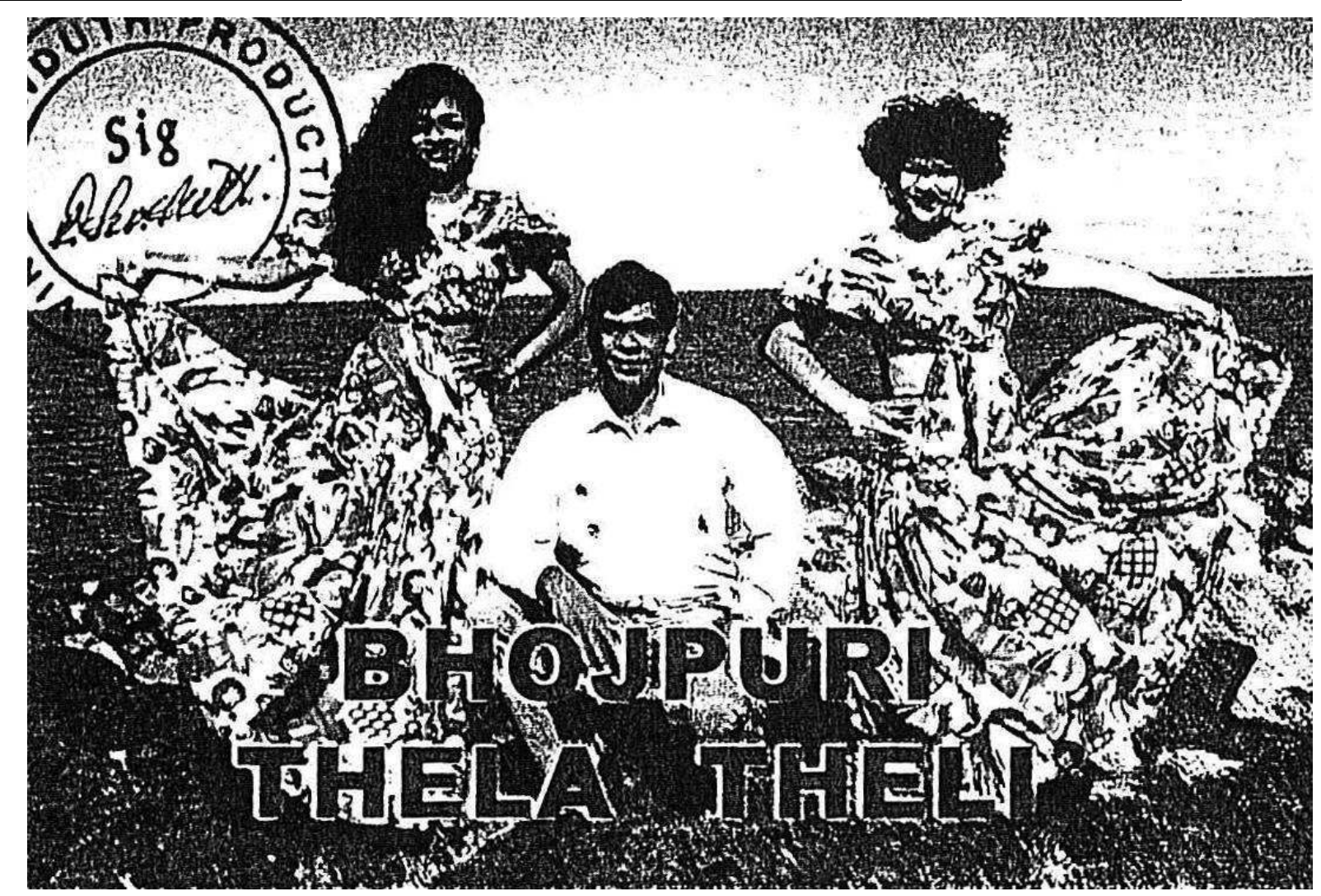

\section{Conclusion}

[41] As underlined by Rajend Mesthrie (1992) in his study on Language in Indenture: A Sociolinguistic History of Bhojpuri-Hindi in South-Africa, 'symbolic attachment to Indian languages in term of watching films, performing prayers, listening to music and songs are aspects much underestimated in the study of migration and diaspora'. Yet, this statement immediately brings to mind Peter Manual's (2000: 2) question about the paradoxical role of music in the Caribbean migratory context: 'the chutney vogue is profoundly and dynamically contradictory, reflecting at once the revival and the dilution of Indo-Caribbean culture. But it serves also a new national culture'. Indeed, how to forget the influence of the musical field in the debate on 'Creole future or modernized Indianity' (Hookoomsing 2000: 203)?

[42] Whereas sega performance, including musical instruments costumes and choreography, is usually presented as nourished in part by Indian aesthetics, ${ }^{13}$ a different approach was emphasized

13 Some Mauritian scholars or musicians consider the ravanne as a South Indian drum. Some also say that the costume of the ségatières is inspired by an Indian clothing, and that the choreography borrows from Indian folk village dances. 
Servan-Schreiber, Catherine (2011) 'Indian Folk Music and 'Tropical Body Language': The Case of Mauritian Chutney', South Asia Multidisciplinary Academic Journal. URL: http://samaj.revues.org/index3111.html To quote a passage, use paragraph (§).

here. As far as leisure culture is concerned, Indian communities' diasporic experiences lead to different patterns. In the United States, the Muslim youth of South Asian origin does not appear particularly reluctant to share the quest of happiness and entertainment (fun) of the American society; but it does so with an 'elective attitude' (Mohammad-Arif 2000: 111). The notion of shared leisure implies, for instance, the celebration of common festivals, such as Thanksgiving and Halloween. In the Caribbean chutney culture, the use of English is more developed. The body language, choreographies and lyrics are much more sexually liberated as well.

[43] In the case of the Mauritian musical evolution, transformations continually occur, revealing the influence of reggae, zouk, Bollywood bhangra, raï and Latina dances (Goreau-Ponceaud \& Servan-Schreiber forthcoming). Reggae has left its imprint on sega concert scenography. Some female sega dancers take the posture of reggae feminine choirs, wearing long straight skirts, and high turbans like rasta women. They move about in a chorus line in a much sterner manner than previously. With globalization, all the musical networks, that usually converge in festivals, are in full mutation. A new 'Ragga indiz' style appears. Among the chutney singers, the connections with the Caribbean world, which were first strictly woven through Indian diaspora networks, have changed. They focus more on Afro-Caribbean networks.

[44] In Mauritius, the popularity of Creole sega, now considered to be a national music, remains superior to any other. The transformation of the Indian folk style, beyond choreographical and musical fields, has not only changed its relationship with the wider Mauritian society, but also the inter-community dynamic within the South Asian diaspora itself. As an expression of hybridized culture and identity, chutney symbolizes communal de-compartmentalization in Mauritius, leading to a celebration of Mauritian pluralism per se. It reveals the transversal nature of the relationship between hitherto distinctly defined, separate, Indian and Creole communities. More generally, this turn towards new sources of inspiration demonstrates the cultural autonomy of the Indian diaspora vis-à-vis the centre. It reveals the creativity of musicians in the diaspora, and underlines the role of music and dance as genres most likely to reflect social mutations, and as being themselves agents of further transformation.

[45] As Monique Desroches points out,

Musical phenomena in societies in diaspora cannot be understood in the same way as in traditional sedentary societies. Migration, voluntary or forced, sets off mechanisms of adjustment within both migrant and host communities. More importantly, distancing over space and time transforms social, cultural and 
Servan-Schreiber, Catherine (2011) 'Indian Folk Music and 'Tropical Body Language': The Case of Mauritian Chutney', South Asia Multidisciplinary Academic Journal. URL: http://samaj.revues.org/index3111.html To quote a passage, use paragraph (§).

religious values, leading migrants to define themselves in relation to their current social context quite as much as their origins (Desroches 2003: 216).

[46] On questions of identity expression, and especially of cultural creation in diaspora, chutney throws new light on modes of artistic production and on the transformation of cultural heritage in migratory situations. It especially shows the ever more distant links between music as practiced in the 'source country' (India) and in Mauritius, in contrast with the ever closer contact and relationship amongst neighbouring diasporic communities (within the West Indies, the Indian Ocean, etc.) Hence, the study of chutney can afford new insights into the study of diaspora, overly centred on 'vertical' relationships of diasporic communities with their states of origin or adoption, neglecting the equally important recognition of 'horizontal' relations between diasporic communities (Ma Mung 2005).

[47] In the Mauritian musical field, the spirit of competition cannot but recall the competition between Hindus and Creoles in Surinam as studied by Maurits Hassankhan (1997). But much more than this is involved. As a result of the creolization of musical forms and perceptions, a feeling of distance from the country of origin pervades, as well as a sentiment of a shared Mauritian identity. As put by Ramesh (a 63-year-old cosmetics salesman), 'when we go back to India, we are very pleased. Our heart is touched. But very quickly, when we look at Indian people, we realize we are different. They are stiff, they do not know how to bouze-bouzer (move). We know how to move our hips and bottoms. We are Mauritians' (Ramesh 2007). The progressive replacement of the term chutney by 'sega Bollywood' shows the recognition of the creolization process, and legitimates two influences: an ancient one, from Africa, and a new one, from India. Even though it may be adopted for commercial purposes, in the perspective of being granted a 'World Music label' so to speak, it reveals a deep change. Though keeping its own specificity and historicity, chutney music is undergoing an evolution which now takes it beyond the island of Mauritius. The islands of the Indian Ocean produce various types of music; in order to understand their dynamics and future transformations, it is now necessary to gather and compare information on how cultural industries and forms from African, Creole, or Indian networks circulate. ${ }^{14}$

\footnotetext{
14 I would like to thank Kathleen Scarboro and Akshay Bakaya for their helpful rereading and comments on this text as well as my anonymous Samaj referees.
} 


\section{References}

Andrieu, Sarah (2008) 'Savoirs dansés en circulation et réagencement du rapport au passé. La création chorégraphique contemporaine au Burkina Faso', unpublished paper, presented at the conference Composer, imaginer, innover: la création musicale en contexte global, Paris: INHA, 10 December.

Assonne, Sedley (2004) Gérard Louis. Tout pour la musique, Port-Louis: Crystal Editions.

Ballgobin, Veena; Antoine, Marclaine (2003) 'Traditionnal Musical Instruments from Oral Traditions: Folk Music in Mauritius', Revi Kiltir Kreol, 3, October, pp. 69-82.

Beeharry, Deepchand (1976) That Others Might Live, Delhi: Orient Paperbacks.

Bhagat-Ramyad, Gawtami (2007) Global Impact of Indian Music. With Special Reference to Mauritius, New Delhi: Sanjay Prakasha.

Blom Hansen, Thomas (2006) 'Sounds of Freedom: Music, Taxis and Racial Imagination in Urban South Africa', Public Culture, 18 (1).

Boodhoo, Sarita (1993) Kanya Dan: The Why of Hindu Marriage Rituals, Port-Louis: Mauritius Bhojpuri Institute.

Boodhoo, Sarita (1999) Bhojpuri Traditions in Mauritius, Port-Louis: Mauritius Bhojpuri Institute.

Boodnah, Hurry (2006). Interview by author, 25 February, Petit-Sable.

Boswell, Rosabelle (2006) 'Le Malaise Créole': Ethnic Identity in Mauritius, New York \& Oxford: Berghahn Books.

Carsignol, Anouck (2009) La diaspora et l'Etat-nation sur la scène internationale: une étude de la population indienne à l'lle Maurice et au Canada, Ph. D dissertation, Geneva: Institut des Hautes Etudes Internationales et du Développement.

Corbin, Alain (2001) L'Homme dans le paysage: entretien avec Jean Lebrun, Paris: Editions Textuel.

Deepoa, Biswanee (2007). Interview by author, 29 January, Nouvelle-Découverte.

Desroches, Monique (1994) 'Musique-fusion ou quand la diaspora indienne se met au diapason', in Gerry L'Etang (ed.), Présence de l'Inde dans le Monde, Paris: L'Harmattan.

Desroches, Monique (1996) Tambour des dieux. Musique et sacrifice d'origine tamoule à la Martinique, Paris: L'Harmattan.

Desroches, Monique (2003) 'Musique, rituel et construction du savoir', in Monique Desroches \& Ghyslaine Gertin (eds.), Construire le savoir musical. Enjeux épistémologiques, esthétiques et sociaux, Paris: L'Harmattan, pp. 207-18.

Desroches, Monique; Gertin, Ghyslaine (eds.) (2003) Construire le savoir musical. Enjeux épistémologiques, esthétiques et sociaux, Paris: L'Harmattan. 
Servan-Schreiber, Catherine (2011) 'Indian Folk Music and 'Tropical Body Language': The Case of Mauritian Chutney', South Asia Multidisciplinary Academic Journal. URL: http://samaj.revues.org/index3111.html To quote a passage, use paragraph (§).

Djebbari, Elina (2008) 'Recomposer la tradition, créer la modernité. Les grands ballets nationaux d'Afrique de l'Ouest et les nouvelles compagnies de ballet: l'exemple du Mali', unpublished paper, presented at the conference Composer, imaginer, innover: la création musicale en contexte global, Paris: INHA, 10 December.

Dorin, Stéphane (2005) La globalisation des formes culturelles. Le jazz et le rock à Calcutta, Ph. D dissertation, Paris: EHESS.

Ebr.-Vally, Rehana (2005) 'Migration of an Identity: South Africans of Indian descent', in Philippe Gervais-Lambony; Frédéric Landy \& Sophie Oldfield (eds.), Reconfiguring Identities and Building Territories in India and South Africa, Delhi: Manohar, pp. 221-32.

Eisenlohr, Patrick (2007) Little India: Diaspora, Time and Ethnolinguistic Belonging in Hindu Mauritius, Berkeley: University of California Press.

Gilroy, Paul (2003) L’Atlantique noir. Modernité et double conscience, Paris: Editions Kargo.

Goreau-Ponceaud, Anthony; Servan-Schreiber, Catherine (forthcoming) 'Black Waters et Black Atlantic: quel teint pour la musique indienne en diaspora?', Géographie et Cultures.

Gowry Brothers (2007). Interview by author, 20 February, Vacoas.

Guillebaud, Christine (2008a) Le chant des serpents. Musiciens itinérants du Kérala, Paris: Editions du CNRS.

Guillebaud, Christine (2008b) 'Processus de création dans l'industrie de la musique folk au Kérala', unpublished paper, presented at the conference Composer, imaginer, innover: la création musicale en contexte global, Paris: INHA, 10 December.

Hassankhan, Maurits (1997) 'Competition and Co-operation: East Indians and Creoles in Suriname's Politics', unpublished paper presented at a CSA Conference, Barranquilla (Colombia).

Hookoomsing, Vinesh (2000) 'Nu dan nu pei, Nu gran pei dan nu ', in Jean Barnabé; Jean-Luc Bonniol; Raphaël Confiant \& Gerry L'Etang (eds.), Au Visiteur lumineux. Des îles créoles aux sociétés plurielles. Mélanges offerts à Jean Benoist, Cayenne: Ibis Rouge Editions, pp. 203-16.

Jayaram, N. (2003) 'The politics of 'Cultural Renaissance' among Indo-Trinidadians', in Bhikhu Parekh; Gurhapal Singh \& Steven Vertovec (eds.), Culture and Economy in the Indian Diaspora, London: Routledge, pp. 123-41.

Lagare, Freeman (1999) 'Aawa, mila Louis Freeman Lagare se. Rencontrez LFL', Rencontres avec l'Inde, XXVIII, 1, pp.181-92.

Lagare, Freeman (2006). Interview by author, 23 February, Forest Side.

Landy, Frédéric (2005) 'Land of the Ancestors and Territory of the Diaspora: the Example of the 'Indian' South Africans', in Philippe Gervais-Lambony; Frédéric Landy \& Sophie Oldfield (eds.), Reconfiguring Identities and Building Territories in India and South Africa, Delhi: Manohar, pp. 20319. 
Servan-Schreiber, Catherine (2011) 'Indian Folk Music and 'Tropical Body Language': The Case of Mauritian Chutney', South Asia Multidisciplinary Academic Journal. URL: http://samaj.revues.org/index3111.html To quote a passage, use paragraph (§).

Larkin, Brian (2002) 'Bandiri Music, Globalization and Urban Experience in Nigeria', Cahiers d'Etudes Africaines, 4 (168), pp. 739-62.

Le Chartier, Colette (1995) Ti-Frère poète du quotidien, Port Louis (lle Maurice): Centre Culturel Africain.

Legrand, Géraldine (2005) 'Bhojpuri Boys, la Renaissance', Week-End-Scope.

Le Menestrel, Sara (2010) 'Introduction', unpublished paper presented at the workshop Anthropologie de la musique et de la danse: une approche des mondes contemporains, Musmond program (ANR), 8 juin.

Leymarie, Isabelle (1996) Musiques Caraïbes, Paris: Actes Sud \& Cité de la musique.

Mallet, Julien (2008) 'Les musiciens de tsapiky, des 'marginaux de l'intérieur' porteurs d'une jeune musique qui fait danser les ancêtres (Madagascar)', unpublished paper presented at the conference Composer, imaginer, innover: la création musicale en contexte global, Paris: INHA, 10 December.

Ma Mung, Emmanuel (2005) 'Immigration and Ethnic Labour Market', in Felicitas Hillmann; Ernst Spaan \& Ton Van Naerssen (eds.), Asian Migration and Labour Market Integration in Europe, London: Routledge.

Manuel, Peter (1998) 'Chutney and Indo-Trinidadian Cultural Identity', Popular Music, 17 (1), pp. 21 43.

Manuel, Peter (2000) East-Indian Music in the West Indies. Tan-singing, Chutney, and the Making of Indo-Caribbean Culture, Philadelphia: Temple University Press.

Martin, Denis-Constant (2002) 'Le Cap ou les partages inégaux de la créolité sud-africaine', Cahiers d'Etudes Africaines, 4 (168), pp. 687-710.

Massamba, Christophe Vividila (2003) Constructions identitaires et musique: le séga aujourd'hui. Essai sur les représentations socioculturelles du séga chez les jeunes Mauriciens de la diaspora en France, Master Dissertation, Paris: Université Paris VII.

Menger, Pierre-Michel (2001) Le paradoxe du musicien. Le compositeur, le mélomane et l'Etat dans la société contemporaine, Paris: L'Harmattan.

Mesthrie, Rajend (1992) Language in Indenture. A Sociolinguistic History of Bhojpuri-Hindi in South Africa, London: Routledge and Kegan.

Mohammad-Arif, Aminah (2000) Salam America: l'islam indien en diaspora, Paris: CNRS Editions.

Myers, Helen (1993) 'Regional Studies: the West Indies', in Helen Myers (ed.), Ethnomusicology, Historical and Regional Studies, New-York \& London: W.W. Norton Company (The Norton/Grove Handbooks in Music), pp. 460-71.

Myers, Helen (1998) Music of Hindu Trinidad. Songs from the India Diaspora, Chicago: Chicago University Press. 
Servan-Schreiber, Catherine (2011) 'Indian Folk Music and 'Tropical Body Language': The Case of Mauritian Chutney', South Asia Multidisciplinary Academic Journal. URL: http://samaj.revues.org/index3111.html To quote a passage, use paragraph (§).

NgCheong-Lum, Rosaline (2003) Culture Shock! Mauritius, Singapore: Times Book International.

Nuckcheddy, Jasmundeo (2006). Interview by author, 16 March, Quatre-Bornes.

Nundlall, Ishwarduth (1976) Music in Mauritius, Vacoas: Sargam Publications.

O'Henry, Edward (1988) Chanting the Name of God. Music and Culture in Bhojpuri Speaking India, San Diego: San Diego University Press.

Onnk, Gijsbert (2005) 'Asians in Africa, images, histories and portraits', IIAS Newsletter, 39, p. 18.

Ramdin, Suchita (1984) Sanskar Manjari. Manrisas ke sanskar Git (Mauritius Bhojpuri Sacrament Songs from Birth to Death), Moka: Mahatma Gandhi Institute.

Ramdin, Suchita (2006). Interview by author, Nouvelle France.

R., Ramesh (2007). Interview by author, 18 January, Port-Louis.

Ramessur, Anilsingh (2007). Interview by author, 23 February, Port-Louis.

Ramnarine, Tina Karina (1996) "Indian' Music in the Diaspora: Case Study of 'Chutney' in Trinidad and in London', British Journal of Ethnomusicology, 5, pp. 132-51.

Rengasamy, Baby (2002) 'Abeydhanand Beejan: Chutney inspirations', Week-End Scope, 1-7 February.

Ricaud, Claudie (1993) 'Le séga, re-création dans les traditions orales', Notre Librairie, 114, JulySeptember, pp. 130-3.

Samson, Guillaume (2006) Musique et identité à la Réunion. Généalogie des constructions d'une singularité musicale insulaire, Ph. D Dissertation, Montreal \& Aix: Montreal \& Université d'AixMarseille III.

Samson Guillaume (2008) 'Patrimoine et création musicale contemporaine à La Réunion', unpublished paper, presented at the conference Composer, imaginer, innover: la création musicale en contexte global, Paris: INHA, 10 December.

Servan-Schreiber, Catherine (1999) Chanteurs itinérants de l'Inde du Nord. La tradition orale bhojpuri, Paris: L'Harmattan.

Servan-Schreiber, Catherine (2003) 'Tellers of Tales, Sellers of Tales: Bhojpuri Peddlars in Northern India', in Claude Markovits; Jacques Pouchepadass \& Sanjay Subrahmanyam (eds.), Society and Circulation. Mobile People and Itinerant Cultures in South-Asia 1750-1950, New Delhi: Permanent Black, pp. 275-305.

Servan-Schreiber, Catherine (2010) Histoire d'une musique métisse à l'île Maurice. Chutney indien et séga Bollywood, Paris: Editions Riveneuve.

Servan-Schreiber, Catherine (forthcoming) 'Sources littéraires pour l'histoire des villes et de la sociabilité urbaine mauriciennes', in Faranirina Rajaonah; Jocelyn Chan Law \& Prosper Eve (eds.), 
Servan-Schreiber, Catherine (2011) 'Indian Folk Music and 'Tropical Body Language': The Case of Mauritian Chutney', South Asia Multidisciplinary Academic Journal. URL: http://samaj.revues.org/index3111.html To quote a passage, use paragraph (§).

Multiculturalisme, échanges et métissages culturels dans les villes de l'océan Indien occidental (XVIIle-XXIe siècles).

Sewpaul, Basant (2006). Interview by author, 3 March, Rivière-des-Créoles (Mahébourg).

Sowamber, Ravin (2003). Interview by author, 15 April, Grand Baie.

Tarabout, Gilles (2003) 'Passage à l'art. L'adaptation d'un culte sud indien au patronage artistique', in Yolaine Escande \& Jean-Marie Schaeffer (eds.), L'esthétique: Europe, Chine et ailleurs, Paris: Editions You-Feng, pp. 37-60.

Toffin, Gérard (1988) 'Zola entre ethnologie et fiction', Critique, 498, pp. 895-902.

Vertovec, Steven (1992) Hindu Trinidad: Religion, Ethnicity and Socio-Economic Change, London and Basingstoke: Macmillan Press. 